\title{
Use of Organic Acids for Controlling Damping-off Caused by Rhizoctonia solani on
} Cotton

Eman A. M. Osman ${ }^{1}$; Shereen E. M. El Nahas ${ }^{1}$; Maryan M. Youssef ${ }^{2}$ and Maggie E. M. Hassan $^{1}$

${ }^{1}$ Plant Pathology Research Institute, Agricultural Research Center, Giza,Egypt

${ }^{2}$ Plant Pathology Department, Faculty of Agriculture, Cairo University, Egypt

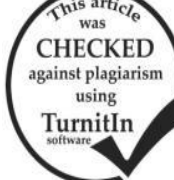

\section{ABSTRACT}

The four organic acids; Gallic acid (GA), Jasmonic acid (JA), Oxalic acid (OA) and Tannic acid (TA); (used in three concentrations for each acids) were evaluated in vitro and in vivo for suppression of Rhizoctonia solani caused damping-off on cotton. In vitro study showed that JA and OA were ineffective in inhibiting linear growth of the fungus, while GA and TA showed antifungal activities. In non-infested soil, none of the tested acids caused phytotoxicity under greenhouse conditions for seedlings of cotton cultivar Giza 95 when they were applied as soil drench. All the organic acids caused significant increases in plant height and dry weight of seedlings. In infested soil, GA was effective in controlling damping-off disease only at the low concentration (25.0 mM). All the applied concentrations of the other acids were effective in controlling the disease. Plant height and dry weight were not affected by any acid. The effects of organic acids on peroxidase, polyphenol oxidase, free phenolic compounds and total phenolic compounds were variable depending upon the applied concentration.

Keywords: Organic acids, Rhizoctonia solani, Damping-off, Cotton

\section{INTRODUCTION}

Rhizoctonia solani Kühn [(Thanatephorus cucumeris) (Frank) Donk] is a soil plant pathogen having worldwide distribution, a great ecological diversity and a vast host range. The pathogen is the most important soil borne fungus associated with cotton (Gossypium barbadense L.) damping off in Egypt (Moustafa et al., 1993).

The pathogen usually attacks cotton seed or seedlings during germination and initial establishment of plants in the soil (Watkins, 1981). The use of seed dressing fungicides for controlling the disease is a common strategy. Rani et al. (2017) mentioned that fungicides affect adversely on soil fertility, soil microorganisms and other organisms like earthworms and even biological nitrogen fixing bacteria. Fungicides also cause soil and ground water pollution and have hazardous effect on human being who applies them. Moreover, use of fungicides led to development of fungicides resistant strains of the pathogen.

The phenomenon by which a plant's own defense mechanisms are induced due to prior treatment with either biological or chemical agent is known as Systemic Acquired Resistance (SAR) (Sticher et al., 1997). Induction of resistance in plants to overcome pathogen infection by using some chemicals is a promising approach for controlling plant diseases (El-Mohamedy et al., 2014).

Many studies have been conducted on chemical resistance inducers used for controlling root rot under greenhouse and field conditions (El-Mougy et al., 2004; and El-Mohamedy et al., 2014).

No doubt these chemicals are environmentally safe, economically cheaper and easy to apply with much less hazards comparing with conventional fungicides (Hassan et al., 2007).

Jasmonic acid has been found to increase plant tolerance to variety of biotic and abiotic stresses including fungal pathogens (Fugate et al., 2017).

Tannic acid occurs widely in root exudates, decaying plant residues and soil. It served as an ecological allelochemical, repressing the growth of the pathogen $(\mathrm{Wu}$ et al., 2010).

Gallic acid seems to have antifungal activity against Fusarium semitectum, $F$. fusiformis and Alternaria altternata (Al-Zahrani, 2012).
Oxalic acid (OA) is known to induce high level of systemic resistance in oil seed against Sclerotinia sclerotiorum (Toal and Jones 1999). Exogenous application of OA caused induction of resistance in rice plants against $R$. solani infection (Jayaraj et al., 2010).

The host-pathogen interaction induces signaling molecule in plants system, which lead to production of antimicrobial compound. Defensive enzymes are among the most influential and widely distributed products in the plants. Peroxidase and polyphenol oxidase were reported in plants treated with various biotic and abiotic inducers (Raghvendra et al., 2007). The role of oxidative enzymes such as peroxidase and polyphenol oxidase could be explained as anoxidation process of phenol compounds to oxidized products which may limit the fungal growth (Nawar and Kuti, 2003). The chemical inducers might stimulate some defense mechanisms such as phenolic compounds, oxidative enzymes (Amel et al., 2010; and ElMohamedy et al., 2014).

The objective of the present study was to investigate the effects of some organic acids on protection of cotton (Gossypium barbadense L.) cultivar Giza 95 against damping-off disease caused by Rhizoctonia solani under greenhouse conditions and to detect the impacts of the tested acids on some defense mechanisms (oxidative enzymes and phenolic compounds) of cotton against infection.

\section{MATERIALS AND METHODS}

\section{Source of fungal pathogen:}

Rhizctonia solani isolate used in this study was obtained from the fungal collection of Cotton and Fiber Crops Dis. Res. Sec., Plant Pathology Res. Inst. Agric. Res. Center. The isolate was originally isolated from cotton seedling infected with damping-off.

Effect of organic acids on fungal linear growth:

In vitro antifungal assays of the organic acids against the fungus were performed with the poisoned plate technique as described by (Adawy et al., 2018).

Effect of organic acids on growth of cotton cultivar Giza 95 under greenhouse conditions:

Autoclaved clay soil was dispended in sterilized 15$\mathrm{cm}$ diameter clay pots and planted with 10 seeds of cotton cultivar Giza 95. The tested acids solutions were added to 
the pots $(50 \mathrm{ml} / \mathrm{pot})$ at three replicates for each concentration and after forty days stand, plant height and dry weight were recorded (Table 2). Random samples of cotton seedlings were collected from each treatment and used for further biochemical studies.

Effect of organic acids on damping-off incidence under greenhouse conditions:

Substrate for growth of $R$. solani isolate was prepared in $50 \mathrm{ml}$ flasks, each flask contained $15 \mathrm{gm}$ of sorghum grains and $25 \mathrm{ml}$ of water. Contents of flasks were autoclaved for $30 \mathrm{~min}$. The autoclaved flasks were inoculated with fungal growth taken from one-week old culture on Potato Dextrose Agar medium (PDA) plates and allowed to colonize sorghum for 7 days. Autoclaved clay soil was infested with the isolate of $R$. solani at the rate of $1.0 \mathrm{~g} / \mathrm{kg}$ soil. Infested soil was dispended in sterilized 15$\mathrm{cm}$ diameter clay pots and planted with 10 seeds of cotton cultivar Giza 95 with three replicates for each treatment. Three replicates contained autoclaved soil served as control. Solution of each concentration $(50 \mathrm{ml} / \mathrm{pot})$ of each tested acid was added to each replicate (Table 3). After forty days disease incidence, plant height and dry weight of plants were recorded. Random samples of cotton seedlings were collected from each treatment and used for further biochemical studies.

Preparation of enzyme extracts and the assay methods

Crude enzyme extracts for the assays were prepared according to (Aluko and Ogbadu, 1986). The Enzymes activity was assayed using spectrophotometer (spectronic 106).

\section{Peroxidase enzyme assays}

The Peroxidase activity was measured in different samples as described by (Worthington, 1972) as follows: An amount of $0.5 \mathrm{ml} \mathrm{mL}$ diluted extracts was mixed with

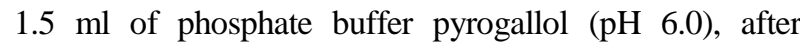
mixing; the solution was added $1.1 \mathrm{ml} \mathrm{H} 2 \mathrm{O} 230 \%$. The change absorbance of the reaction mixtures was measured against blank at $430 \mathrm{~nm}$ wavelength $(\Delta 430)$.

Polyphenol oxidase enzyme assays

Polyphenol oxidase activity was measured following the method described by (Esterbaner et al., 1977). The enzyme extract $(0.5 \mathrm{~mL})$ was mixed with 2.2 $\mathrm{ml}$ of $0.1 \mathrm{M}$ phosphate buffer. After the sample was adjusted to zero absorbance, $0.5 \mathrm{ml}$ of $0.01 \mathrm{M}$ catechol in $0.1 \mathrm{M}$ phosphate buffer was added to the mixture and the volume was made up to $3 \mathrm{~mL}$ with distilled water. The reaction was quickly mixed and after the change in absorbance per minute was measured at $495 \mathrm{~nm}(\Delta 495)$.

\section{Determination of phenolic compounds}

The total and free phenols of the extracts were determined using the Folin and Ciocalteu reagent, following the method described by (Simons and Ross, 1971). Sample and standard readings were made using a spectrophotometer (spectronic 106 spectrophotometer) at $520 \mathrm{~nm}$ against the reagent blank.

Statistical analysis

The obtained data were statistically analyzed by MSTAT-C software. The mean differences were compared by least significant difference test (LSD) at $\mathrm{p}$ $\leq 0.05$.

\section{RESULTS}

Effect of the organic acids on linear growth of $\boldsymbol{R}$. solani on PDA medium:

Table (1) showed that GA caused significant inhibition $(57.44 \%)$ on linear growth only at the high concentration $(105.0 \mathrm{mM})$. Each of JA and OA did not cause inhibition of $R$. solani linear growth at all concentration. In contrast, TA caused significant inhibition $68.11 \%, 55.89 \%$ and $47.44 \%$ on linear growth at all used concentrations in comparison with the control.

Table 1. Effect of organic acids on linear growth of $\boldsymbol{R}$. solani on PDA medium

\begin{tabular}{lccc}
\hline $\begin{array}{l}\text { Organic } \\
\text { Acid }\end{array}$ & $\begin{array}{c}\text { Applied } \\
\text { Concentration(Mm) }\end{array}$ & $\begin{array}{c}\text { Linear } \\
\text { Growth(cm) }\end{array}$ & $\begin{array}{c}\text { Inhibition } \\
(\boldsymbol{\%})\end{array}$ \\
\hline Control & -- & $9.00^{\mathrm{a}}$ & \\
\hline \multirow{3}{*}{ Gallic acid } & 105.00 & 3.83 & $57.44^{\mathrm{b}}$ \\
& 55.00 & 8.67 & 3.67 \\
& 25.00 & 9.00 & 0.00 \\
\hline \multirow{3}{*}{ Jasmonicacid } & 0.20 & 9.00 & 0.00 \\
& 0.10 & 9.00 & 0.00 \\
& 0.05 & 9.00 & 0.00 \\
\hline \multirow{3}{*}{ Oxalic acid } & 2.00 & 9.00 & 0.00 \\
& 1.00 & 9.00 & 0.00 \\
& 0.50 & 9.00 & 0.00 \\
\hline \multirow{3}{*}{ Tannic acid } & 20.00 & 2.87 & 68.11 \\
& 10.00 & 3.97 & 55.89 \\
\hline a & 5.00 & 4.73 & 47.44 \\
\hline
\end{tabular}

${ }^{a}$ Mean of three replicates

${ }^{\mathrm{b}}$ Inhibition \% = (control-treatment /control) $\mathbf{x 1 0 0}$

$\operatorname{LSD}(p \leq 0.05)=0.41$

Effect of organic acids on cotton seedlings grown in non-infested soil:

Data in Table (2) showed that the tested acids had no significant effects on percentage of seedling stand compared with control, while all treatments significantly increased each of the plant height and dry weight of seedlings compared with control. None of the tested acids showed phytotoxicity on seedlings of cotton cultivar Giza 95.

Table 2. Effect of organic acids on cotton seedlings (cv. Giza 95) grown in non-infested soil

\begin{tabular}{lcccc}
\hline $\begin{array}{l}\text { Organic } \\
\text { Acid }\end{array}$ & $\begin{array}{c}\text { Applied } \\
\text { Concentration } \\
(\mathbf{M m})\end{array}$ & $\begin{array}{c}\text { Stand } \\
(\boldsymbol{\%})\end{array}$ & $\begin{array}{c}\text { Plant } \\
\text { height } \\
(\mathbf{c m} / \text { plant })\end{array}$ & $\begin{array}{c}\text { Dry } \\
\text { weight } \\
(\mathbf{g m} / \text { plant })\end{array}$ \\
\hline Control & -- & $86.70^{\mathrm{a}}$ & 14.89 & 0.085 \\
\hline \multirow{3}{*}{ Gallic acid } & 105.00 & 73.30 & 19.40 & 0.190 \\
& 55.00 & 73.30 & 20.67 & 0.175 \\
& 25.00 & 66.70 & 22.40 & 0.249 \\
\hline \multirow{3}{*}{ Jasmonicacid } & 0.20 & 86.70 & 20.32 & 0.197 \\
& 0.10 & 93.30 & 22.00 & 0.214 \\
Oxalic acid & 0.05 & 86.70 & 20.10 & 0.205 \\
\hline \multirow{3}{*}{ Tannic acid } & 2.00 & 73.30 & 22.20 & 0.262 \\
& 1.00 & 80.00 & 20.74 & 0.236 \\
& 0.50 & 80.00 & 24.33 & 0.325 \\
\hline LSD $\leq 0.05)$ & 20.00 & 73.33 & 26.14 & 0.338 \\
\hline
\end{tabular}

${ }^{\mathrm{a}}$ Mean of three replicates 
Effect of organic acids on cotton seedlings (cv. Giza 95) grown in infested soil with $R$. solani:

Data in Table (3) showed that $R$. solani caused significant decrease $(43.33 \%)$ in seedling survival compared with non-infested soil (86.67\%). The fungicide (Moncut) caused significant increase in seedling survival (93.33\%) compared with seedling survival in infested soil. Gallic acid caused significant decrease $(20.0 \%)$ in seedling survival when it used by high concentration $(105.0 \mathrm{mM})$ and medium concentration $(55.0 \mathrm{mM})$, while it increased $(53.33 \%)$ the survived seedlings at low concentration $(25.0 \mathrm{mM})$, but this increase was not significant. All the other tested acids caused significant increases in seedling survival at all concentration except JA at the low concentration $(0.05 \mathrm{mM})$ and $\mathrm{OA}$ at high concentration $(2.0 \mathrm{mM})$ where the increases were not significant. Data in Table (3) also showed that all tested acids at all used concentrations did not cause significant effects on plant height or dry weight.

Effect of organic acids on oxidative enzymes in cotton seedlings grown in non-infested soil:

Data in Table (4) showed that GA caused significant decrease (0.127) in peroxidase at high concentration $(105.0 \mathrm{Mm})$ compared with untreated control (0.704), while it caused significant increases in peroxidase at medium $(55.0 \mathrm{Mm})$ and low $(25.0 \mathrm{Mm})$ concentrations (1.626 and 0.890 , respectively). The same result showed with OA. Jasmonic acid caused significant decreases in peroxidase activity at all used concentrations. In contrary, TA caused significant increases in peroxidase activity at all applied concentrations. Polyphenol oxidase activity significantly decreased under effect of application all tested acids except JA at the high concentration $(0.20 \mathrm{mM})$ and TA at medium concentration $(10.0 \mathrm{mM})$ as it significantly increased (0.118 and 0.106, respectively) compared with untreated control (0.065).

Table 3. Effect of organic acids on cotton seedlings (cv. Giza 95) grown in soil infested with $R$. solani

\begin{tabular}{|c|c|c|c|c|}
\hline $\begin{array}{l}\text { Organic } \\
\text { Acid }\end{array}$ & $\begin{array}{c}\text { Applied } \\
\text { Concentration } \\
(\mathbf{m M}) \\
\end{array}$ & $\begin{array}{c}\text { Surviva } \\
(\%)\end{array}$ & $\begin{array}{c}\text { Plant } \\
\text { height } \\
(\mathrm{cm} / \text { plant })\end{array}$ & $\begin{array}{c}\text { Dry } \\
\text { weight } \\
\text { (gm/plant) }\end{array}$ \\
\hline \multicolumn{2}{|l|}{ Non-infested } & $86.67^{\mathrm{a}}$ & 14.89 & 0.085 \\
\hline Infested control & -- & 43.33 & 17.00 & 0.177 \\
\hline Fungicide(Moncut) & -- & 93.33 & 17.97 & 0.176 \\
\hline \multirow{3}{*}{ Gallic acid } & 105.00 & 20.00 & 17.83 & 0.148 \\
\hline & 55.00 & 20.00 & 16.00 & 0.093 \\
\hline & 25.00 & 53.33 & 15.89 & 0.111 \\
\hline \multirow{3}{*}{ Jasmonic acid } & 0.20 & 80.00 & 15.52 & 0.110 \\
\hline & 0.10 & 80.00 & 16.37 & 0.179 \\
\hline & 0.05 & 53.33 & 19.67 & 0.202 \\
\hline \multirow{3}{*}{ Oxalic acid } & 2.00 & 53.33 & 18.72 & 0.192 \\
\hline & 1.00 & 93.33 & 17.50 & 0.143 \\
\hline & 0.50 & 73.33 & 19.67 & 0.195 \\
\hline \multirow{3}{*}{ Tannic acid } & 20.00 & 86.67 & 20.00 & 0.170 \\
\hline & 10.00 & 80.00 & 18.00 & 0.165 \\
\hline & 5.00 & 80.00 & 19.00 & 0.171 \\
\hline $\operatorname{LSD}(\mathrm{p} \leq 0.05)$ & -- & 19.7 & N.S. & N.S. \\
\hline
\end{tabular}

Table 4. Effect of organic acids on oxidative enzymes in cotton seedlings (cv. Giza 95) grown in noninfested soil.

\begin{tabular}{lccc}
\hline $\begin{array}{l}\text { Organic } \\
\text { Acids }\end{array}$ & $\begin{array}{c}\text { Applied } \\
\text { Concentration } \\
(\mathbf{M m})\end{array}$ & $\begin{array}{c}\text { Peroxidase } \\
\text { Activity } \\
\left(\Delta_{\mathbf{4 3 0}}\right)\end{array}$ & $\begin{array}{c}\text { Polyphenol } \\
\text { oxidase } \\
\text { Activity }\left(\Delta_{\mathbf{4 9 5}}\right)\end{array}$ \\
\hline Control & -- & $0.704^{\mathrm{a}}$ & 0.065 \\
\hline \multirow{2}{*}{ Gallic acid } & 105.00 & 0.127 & 0.033 \\
& 55.00 & 1.626 & 0.020 \\
\hline Jasmonic & 25.00 & 0.890 & 0.024 \\
acid & 0.20 & 0.296 & 0.118 \\
& 0.10 & 0.459 & 0.057 \\
Oxalic acid & 0.05 & 0.249 & 0.0215 \\
\hline \multirow{2}{*}{ Tannic acid } & 2.00 & 0.322 & 0.030 \\
& 1.00 & 0.797 & 0.046 \\
\hline LSD $(\mathrm{p} \leq 0.05)$ & 0.50 & 0.909 & 0.0211 \\
\hline${ }^{\mathrm{a}}$ Mean of three replicates & -- & 1.050 & 0.030 \\
\end{tabular}

Effect of organic acids on phenolic compounds in seedling grown in non-infested soil:

Regarding Table (5), total phenolic compounds significantly increased by using GA only at high concentration $(105.0 \mathrm{Mm}), \mathrm{OA}$ at high $(2.0 \mathrm{Mm})$ and low $(0.5 \mathrm{Mm})$ concentrations $(5.609, \quad 5.933$ and 6.142, respectively) compared with untreated seedlings (4.855). Tannic acid caused significant increase in total phenolic compounds at all used concentrations compared with untreated seedlings, while JA caused significant decrease in total phenolic compounds. On the other hand, free phenolic compounds significantly increased by application $\mathrm{OA}$ at low concentration $(0.5 \mathrm{Mm})$ and at all TA concentrations compared with control (4.72).

Table 5. Effect of organic acids on phenolic compounds in cotton seedlings (cv. Giza 95) grown in noninfested soil.

\begin{tabular}{|c|c|c|c|}
\hline $\begin{array}{l}\text { Organic } \\
\text { Acids }\end{array}$ & $\begin{array}{c}\text { Applied } \\
\text { Concentration } \\
(\mathrm{Mm}) \\
\end{array}$ & $\begin{array}{c}\text { Total Phenolic } \\
\text { Compounds } \\
\text { (mg/g fw) }\end{array}$ & $\begin{array}{l}\text { Free Phenolic } \\
\text { Compounds } \\
(\mathrm{mg} / \mathrm{g} \text { fw*) }\end{array}$ \\
\hline \multirow[t]{2}{*}{ Control } & -- & $4.855^{\mathrm{a}}$ & 4.702 \\
\hline & 105.00 & 5.609 & 2.437 \\
\hline \multirow[t]{2}{*}{ Gallic acid } & 55.00 & 4.409 & 3.293 \\
\hline & 25.00 & 4.035 & 2.854 \\
\hline \multirow{3}{*}{ Jasmonic acid } & 0.20 & 4.409 & 3.645 \\
\hline & 0.10 & 4.625 & 3.680 \\
\hline & 0.05 & 4.424 & 4.026 \\
\hline \multirow{3}{*}{ Oxalic acid } & 2.00 & 5.933 & 4.903 \\
\hline & 1.00 & 4.596 & 4.155 \\
\hline & 0.50 & 6.142 & 5.636 \\
\hline \multirow{3}{*}{ Tannic acid } & 20.00 & 6.372 & 5.659 \\
\hline & 10.00 & 7.206 & 5.155 \\
\hline & 5.00 & 6.817 & 5.787 \\
\hline $\mathrm{LSD}(\mathrm{p} \leq 0.05)$ & -- & 0.25 & 0.29 \\
\hline
\end{tabular}

Effect of organic acids on oxidative enzymes in cotton seedling grown in infested soil with $R$. solani:

Table (6) showed that peroxidase activity increased significantly (0.846) in seedlings grown in infested soil compared with seedlings grown in non-infested soil (0.704). The fungicide treatment caused significant increase in peroxidase activity compared with infested control. All treatments caused significant decrease in 
peroxidase except three treatments which were GA at medium concentration, $\mathrm{OA}$ also at medium concentration and TA at high concentration.

Data in Table (6) showed that polyphenol oxidase significantly decreased (0.053) in plants grown in infested soil compared with non-infested control (0.065). All treatments significantly decreased polyphenol oxidase compared with infested control except GA at low concentration (0.09), JA at medium concentration (0.066) and TA at all used concentrations compared with infested control (0.53).

Table 6. Effect of organic acids on oxidative enzymes in cotton seedlings (cv. Giza 95) grown in soil infested with $R$. solani.

\begin{tabular}{|c|c|c|c|}
\hline $\begin{array}{l}\text { Organic } \\
\text { Acids }\end{array}$ & $\begin{array}{c}\text { Applied } \\
\text { Concentration } \\
(\mathrm{Mm}) \\
\end{array}$ & $\begin{array}{c}\text { Peroxidase } \\
\text { Activity } \\
\left(\Delta_{\mathbf{4 3 0}}\right)\end{array}$ & $\begin{array}{c}\text { Polyphenol } \\
\text { oxidase } \\
\text { Activity }\left(\Delta_{495}\right)\end{array}$ \\
\hline Non-infested control & -- & $0.704^{\mathrm{a}}$ & 0.065 \\
\hline Infested control & -- & 0.846 & 0.053 \\
\hline Fungicide(Moncut) & -- & 2.495 & 0.020 \\
\hline \multirow{3}{*}{ Gallic acid } & 105.00 & 0.155 & 0.040 \\
\hline & 55.00 & 2.199 & 0.027 \\
\hline & 25.00 & 0.303 & 0.090 \\
\hline \multirow{3}{*}{ Jasmonic acid } & 0.20 & 0.502 & 0.034 \\
\hline & 0.10 & 0.246 & 0.066 \\
\hline & 0.05 & 0.407 & 0.023 \\
\hline \multirow{3}{*}{ Oxalic acid } & 2.00 & 0.267 & 0.052 \\
\hline & 1.00 & 1.449 & 0.026 \\
\hline & 0.50 & 0.682 & 0.034 \\
\hline \multirow{3}{*}{ Tannic acid } & 20.00 & 1.223 & 0.054 \\
\hline & 10.00 & 0.090 & 0.115 \\
\hline & 5.00 & 0.574 & 0.057 \\
\hline $\operatorname{LSD}(p \leq 0.05)$ & -- & 0.08 & 0.001 \\
\hline
\end{tabular}

${ }^{\mathrm{a}}$ Mean of three replicates.

Effect of organic acids on phenolic compounds in seedlings grown in infested soil with $R$. solani:

Regarding Table (7), total phenolic compounds significantly increased (5.524) in seedlings as a result of $R$. solani infection, compared with seedlings in non-infested soil (4.855). Moncut also caused significant increase (6.796) in total phenolic compounds compared with infested control (5.524). Gallic acid caused significant increase in total phenols at high and medium concentrations (6.868 and 5.962, respectively), while it caused significant decrease (4.452) in total phenols at the low concentration. Jasmonic acid caused increase (5.861) in total phenolic compounds only at the low concentration. Oxalic acid caused significant increase (6.048) in total phenolic compounds at the low concentration. Tannic acid caused increase (5.811) and significant increase (6.271) in total phenolic compounds at the high and low concentrations, respectively.

Presence of $R$. solani in the soil caused significant increase (5.219) in free phenolic compounds in infected seedlings compared with non-infested control (4.702). All treatments caused decrease or significant decrease in free phenolic compounds compared with infested control except the high concentration of TA which caused increase (5.600) in free phenolic compounds.
Table 7. Effect of organic acids on phenolic compounds in cotton seedlings (cv. Giza 95) grown in soil infested with $R$. solani.

\begin{tabular}{|c|c|c|c|}
\hline $\begin{array}{l}\text { Organic } \\
\text { Acids }\end{array}$ & $\begin{array}{c}\text { Applied } \\
\text { Concentration } \\
(\mathbf{M m})\end{array}$ & $\begin{array}{c}\text { Total } \\
\text { Phenolic } \\
\text { Compounds } \\
\text { mg/g fw }\end{array}$ & $\begin{array}{c}\text { Free } \\
\text { Phenolic } \\
\text { Compounds } \\
\text { mg/g fw* }\end{array}$ \\
\hline $\begin{array}{l}\text { Non-infested } \\
\text { control }\end{array}$ & -- & $4.855^{\mathrm{a}}$ & 4.702 \\
\hline Infested control & -- & 5.524 & 5.219 \\
\hline Fungicide(Moncut) & -- & 6.796 & 5.241 \\
\hline \multirow{3}{*}{ Gallic acid } & 105.00 & 6.868 & 4.457 \\
\hline & 55.00 & 5.962 & 4.946 \\
\hline & 25.00 & 4.452 & 3.989 \\
\hline \multirow{3}{*}{ Jasmonic acid } & 0.20 & 5.085 & 4.299 \\
\hline & 0.10 & 4.539 & 4.321 \\
\hline & 0.05 & 5.861 & 4.357 \\
\hline \multirow{3}{*}{ Oxalic acid } & 2.00 & 5.495 & 4.709 \\
\hline & 1.00 & 4.279 & 4.242 \\
\hline & 0.50 & 6.048 & 4.321 \\
\hline \multirow{3}{*}{ Tannic acid } & 20.00 & 5.811 & 5.600 \\
\hline & 10.00 & 4.754 & 4.091 \\
\hline & 5.00 & 6.271 & 5.198 \\
\hline $\operatorname{LSD}(\mathrm{p} \leq 0.05)$ & -- & 0.421 & 0.48 \\
\hline${ }^{\mathrm{a}}$ Mean of three replic & & $v=$ fresh weigh & \\
\hline
\end{tabular}

The antifungal activity of organic acids as we have demonstrated in the present study is in agreement with some previous studies. For example, organic acids play a role for biological soil disinfestations as they suppress the growth of soil pathogens like Fusarium and Rhizoctonia (Noriakiet al., 2006). Zaidi et al. (2008) found a significant inhibiting effect by the TA and GA on the growth of Pectobacterium chrysanhemi. They conducted that TA and GA had biological important effects, as antibacterial, antiviral and antifungal products. Hathout $e t$ al., (2010) found that application of JA as seed presoaking treatment induced systemic resistance of bean plants against $R$. solani. Jayaraj et al., (2010) found that pretreatment of rice plants with OA significantly reduced subsequent infection by $R$. solani. Wu et al., (2010) found that TA decreased the growth and conidial germination of Fusarium oxysporum f. sp. niveum.

Organic acids exert their antifungal activities through a variety of mechanisms. Jasmonic acid (JA) is a naturally occurring hormone that functions as signaling compound for the induction of native plant defense responses (Dar et al., 2015). Jasmonic acid is thought to protect by promoting the synthesis of proteins and metabolites which are toxic, harmful, or anti-nutritive to plant pathogens (Sun et al., 2013). Tannin is a substance that can inhibit the enzyme activities released by $R$. solani and thus potential to be used as antifungal against the fungal species (Achmad et al., 2015). This report lend support to our results which indicate that TA was the most effective acid in suppression $R$. solani damping-off under greenhouse conditions.

Organic acids may alter many parts of the cell and they have an effect on the respiration of the cell (Omar et al., 2018).

The antimicrobial activity of some of the tested organic acids in the present study could be attributed to their stimulation of oxidative enzymes and phenolic 
compounds. The chemical inducers might stimulate some defense mechanisms such as oxidative enzymes and phenolic compounds (Amel et al., 2010 and El-Mohamedy et al., 2014). Lattanzia et al., (2006) mentioned that the highly toxic quinones which produced as a result of oxidization phenols by peroxidase and polyphenol oxidase inhibit fungal germination.

Anand et al., (2009) and Gogoi et al., (2001) reported that the increase in enzymatic activity of peroxidase and polyphenol oxidase stimulate an extra production and piling up of phenolics, which might prevent the pathogen to extend from the infected cells into the uninfected ones, and thus the infection can be suppressed or limited.

The toxic phenolic compounds in plant cells impact through the structure of bond form with cell wall components of plant tissues, encourage host resistant by inducing host defense mechanisms, prohibit the extent of fungal growth in plant tissues and penetrate the microorganisms and cause great damage to the cell metabolisms (Mahadevan and Sridhar, 1986; Subba Rao et al., 1988; Soni et al., 1992; and Kalaichelvan and Elangovan, 1995).

In general, the effects of organic acids on peroxidase, polyphenol oxidase, free phenolic compounds and total phenolic compounds were variable depending upon the applied concentration.

The results of the present study showed that the control of cotton damping-off by GA and TA, particularly TA could be attributed to the two mechanisms of antifungal activity and induced resistance. On the other hand, suppression of the disease by JA and OA was attributed mainly to their induction of Giza 95 resistance. This result indicates that the exact mode of action of controlling damping-off by organic acids depends upon the applied concentration.

The present study is a preliminary work on the efficiency of organic acids in controlling damping-off of cotton seedlings. In the future our attention should focus on field evaluation of organic acids by using a collection of commercial cotton cultivars.

\section{REFERENCES}

Achmad; Firmansyah, M. A.; Soekarno, B. P. W. and Witarto, A. B. 2015. Effects of Tannin to Control Leaf Blight Disease on Toona sureni Merr. Caused by Two Isolates of Rhizoctonia sp. Plant Pathol. J., 14 (3): 148-152.

Adawy, A. I.; El-nahas Shereen, E. M; Mohamed Tahany G. M. and Zaky, M. F. 2018. Synthesis, characterization, formulation, phytotoxicity and in vitro antifungal activity of Schiff base on some important phytopathogenic fungi. J. Basic and Applied Research International 24(6): 237-248.

Aluko R. and Ogbadu GH. 1986. Analysis of eggplant varieties for enzymes related to their organoleptic properties. Trop. Sci. 26: 163 - 171.

Al-Zahrani, Salha H.M. 2012. Antibacterial activities of gallic acid and gallic acid methyl ester on methicillin-resistant Staphylococcus aureus. Journal of American Science, 8(2).
Amel, A. H.; Ahmed. Soad. M. and Ismail, A.A. 2010. Activation of tomato plant defense response against Fusarium wilt disease using Trichoderma harzianum and salicylic acidunder greenhouse conditions. Res. J. Agric. Biol. Sci. 6: 328-338.

Anand, T.; Bhaskaran, R.; Raguchander T.; Samiyappan, R.; Prakasam, V. and Gopalakrishnan, C. 2009. Defense responses of chilli fruits to Colletotrichum capsici and Alternaria alternata. Biol Plant, 53 (3):553-559.

Dar, T.A.; Uddin,M.; Khan,M.M.A.; Hakeem, K.R. and Jaleel, H. 2015. Jasmonates counter plant stress: a review. Environ. Exp. Bot. 115, 49-57.

El-Mohamedy, R.S.R.; Jabnoun-Khiareddine, H. and Daami-Remadi, M. 2014. Control of root rot diseases of tomato plants caused by Fusarium solani, Rhizoctonia solani and Sclerotium rolfsii using different chemical plant resistance inducers. Tunisian Journal of Plant Protection 9: 45-55.

El-Mougy, N.S.; Abd-El-Karem, F.; El-Gamal, N.G. and Fotouh Y.O. 2004. Application of fungicides alternatives for controlling cowpea root rot diseases under greenhouse and field conditions. Egypt. J. Phytopathol. 32: 23-35.

Esterbaner H.; Schwarzl E. and Hayn M. 1977. A rapid assay for catechol oxidase and laccase using 2nitro-5-thio benzoic acid. Anal. Biochem.; 77: 486 494.

Fugate, K. K.; De Oliveira, Lucilene, S.; Ferrareze, J. P.; Bolton, M. D.; Deckard, E. L. and Finger, F. L. 2017. Jasmonic acid causes short- and long-term alterations to the transcriptome and the expression of defense genes in sugar beet roots Plant Gene 9: $50-63$.

Gogoi, R.; Singh, D.V. and Srivastava, K.D. 2001. Phenols as a biochemical basis of resistance in wheat against Karnal bunt. Plant Pathol., 50:470-6.

Hassan, Maggie E. M.; Abd El-Rahman Saieda S.; ElAbbasi I. H. and Mikhail, M.S. 2007. Changes in Peroxidase Activity Due to Resistance Induced Against Faba Bean Chocolate Spot Disease.

Hathout, Tahani, A.; Felaifel, M. S.; El-Khallal, Samia, M.; Gad, Rabab, A. and Hoda, Abo-Ghalia. 2010. Induction of resistance in Phaseolus vulgaris to root rot disease, caused by Rhizoctonia solani, using jasmonic acid. Egypt. J. Agric. Res., 88(1):1-13.

Jayaraja, J.; Bhuvaneswarib, R.; Rabindranb, R.; Muthukrishnana, S. and Velazhahanb, R. 2010. Oxalic acid-induced resistance to Rhizoctonia solani in rice is associated with induction of phenolics, peroxidase and pathogenesis-related proteins. Journal of Plant Interactions 5(2): 147-157.

Kalaichelvan, P.T. and Elangovan, N. 1995. Effect of phenolics on Drechslera oryzae. Indian Phytopathol., 48 (3): 271-274.

Lattanzio, V.; Lattanzio, V.M.T. and Cardinali, A. 2006. Role of phenolics in the resistance mechanisms of plants against fungal pathogens and insects. In: Imperato F, editor. Phytochemistry: advances in research, 37/661(2). Kerala, India Research Signpost, 23-67. 
Mahadevan, A. and Sridhar, K. 1986. Methods of Physiological Plant3rd Edition. Sivakami Pub. Madras.

Moustafa, S. M.; Sumner, D. R.; Ragab, M. M. and Ragab, Mona, M. 1993. Interaction of fungicide, Herbicides, and Planting Date with Seedling Disease of Cotton Caused by Rhizoctonia solani AG-4. Plant Disease 77(1):79.

Nawar, H.F. and Kuti, J.D. 2003. Wyerone acid phytoalexin synthesis and peroxidase activity as markers for resistance of broad beans to chocolate spot disease. J. Phytopathol., 151: 564-570.

Noriaki, M.; Kazuhiro, Y.; Peter, S. and Masahiro, S. 2006. Role of organic acids in the mechanisms of biological soil disinfestation (BSD). J. Gen. Plant Pathol. 72:247-252.

Omar, M. S.; Kordali, S. and Korkmaz, M. 2018. Evaluation of the effect of benzoic acid on some plant pathogenic fungi. Inter. J. Agric. and Natu. Scie.1(1):03-05.

Raghvendra V. B.; Lokesh S.; Govindappa M. and Vasanth K. T. 2007. Dravyaas, an organic agent for the management of seed borne fungi of sorghum and its role in the induction of defense enzymes. Pest.Biochem. Physiol. 89: 190-197.

Rani, A.; Singh, R.; Kumar, P.; and Shukla, G. 2017. Pros and cons of fungicides: an overview. International Journal of Engineering Sciences and Research Technology. 6 (1):112-117.

Simons, T J and Ross AF. 1971. Changes in metabolism associated with enclosed systemic resistance to tobacco. Phytopathology. 61:1261 - 1265.

Soni. G.L.; Sedha, R.K.; Khanna, P.K. and Garcha, H.S. 1992. Growth inhibition of Fusarium oxysporum by phenolic compounds. Indian J. Microbiol, 32: 45-49.
Sticher, L.; Mauch-Mani B. and Metraux, J.P. 1997. Systemic acquired resistance. Annu. Rev. Phytopathol., 35: 235-270.

Subba Rao, P.V.; Geigen, J.P.; Einhorn, J.; Rio., B.; Malosse, C.; Nicole, M.; Savary S. and Ravise, A. 1988. Host defense mechanisms against groundnut rust. Internal. Arahis News lett, 4:16-18.

Sun, D.; Lu, X.; Hu, Y.; Li, W.; Hong, K.; Mo, Y.; Cahill, D.M. and Xie, J. 2013. Methyl

Jasmonate induced defense responses increase resistance to Fusarium oxysporum f. sp. cubense

race 4 in banana. Sci. Hortic. 164, 484-491.

Toal, E. S. and Jones, P. W. 1999. Induction of systemic resistance to Sclerotinia sclerotiorum by oxalic acid in oil seed rape. Plant Pathol. 48:759-767.

Watkins, G. M. 1981. Compendium of cotton disease. The American phytopathological Society. St. Paul., Minnesota.87pp.

Worthington X. X. 1972. Enzyme Manual, Worthington Biochemical Corp., Freehold, New Jersey $41-45$

Wu, H. S.; Liu, Y. D.; Yang, X. I.; Chen, X. Q.; Wang, Z. H.; Kong, X. Y.; Liu, X. X. and Yan, S. 2010. Growth responses of in vitro Fusarium oxysporum f. sp. niveum to external supply of tannic acid. Journal of Environmental Biology 31(6) 10171022.

Zaidi, Y. R.; Zaidi, F. and Bessai, A. A. 2008. Influence of gallic and tannic acids on enzymatic activity and growth of Pectobacterium chrysanthemi (Dickeya chrysanthemi pv. chrysanthemi). African Journal of Biotechnology 7 (4): 482-486.

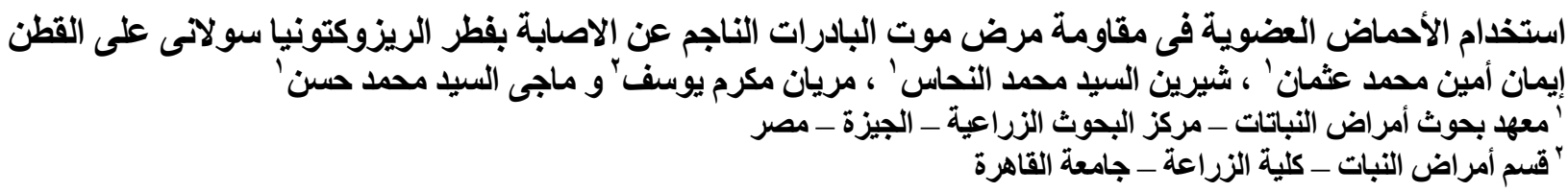

فى هذه الدر اسه قيمت اربعة أحماض عضوية هي حمض الجاليك وحمض الجاسمونيك وحمض الأوكساليك وحمض التانيك) باستخدام

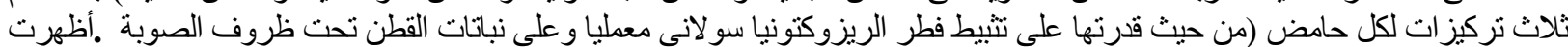

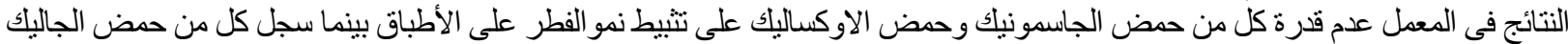

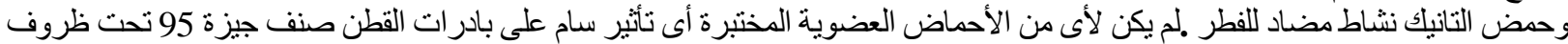

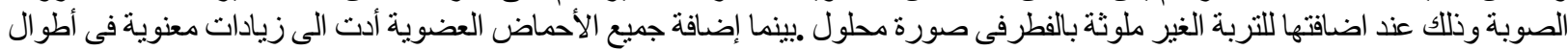

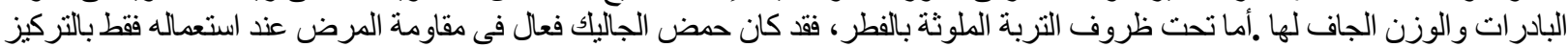

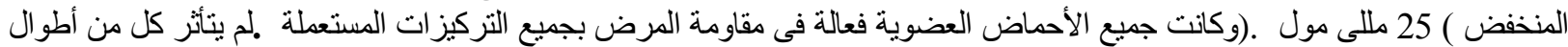

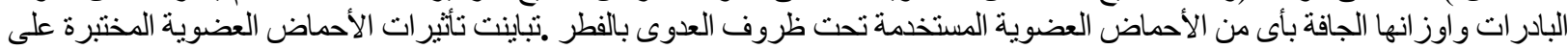

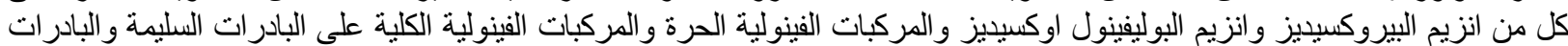

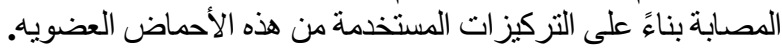

